\title{
Ideology, Access, and Status: Spanish-English Bilinguals in the Foreign- Language Classroom
}

\author{
Michael E. Rolland \\ The Graduate Center, CUNY, New York, USA
}

Article received 25 January 2016, accepted 18 May 2016, final version 26 May 2016

DOI: http://dx.doi.org/10.5565/rev/jt13.680

\begin{abstract}
Spanish language teaching in US higher education is today generally divided between 'foreign language' courses for novice learners and 'heritage language' courses for Hispanic/Latinx students with some knowledge of the language. However, 'heritage' students are a linguistically diverse group, and are also often enrolled at institutions where heritage courses are not offered. Little research to date has studied 'heritage' speakers enrolled in 'foreign' language courses. For this study I conducted semi-structured interviews to explore the affective and ideological characteristics of bilingual students enrolled in elementary Spanish courses. As the literature suggests, I find that these students have a generally low opinion of their own performance in Spanish and a strong bias in favor of the standard language. Finally, in hopes of combating these notions and bridging the divide between heritage and novice learners, I contemplate ways in which students of diverse backgrounds can be included in the same language classroom.
\end{abstract}

Keywords: Spanish, heritage language, language ideology, appropriateness, racialization

\section{Resumen}

La enseñanza del castellano en los EE. UU. se divide generalmente entre cursos de 'lengua extranjera' para aprendices sin conocimientos previos del idioma y cursos 'de herencia' para estudiantes de origen latino/hispano que ya traen algunos conocimientos del español. Hasta la fecha, pocos estudios han examinado la cuestión de los hablantes 'de herencia' inscritos en cursos de tipo 'lengua extranjera.' Para el presente estudio, llevé a cabo entrevistas semiestructuradas para explorar las características afectivas e ideológicas de cuatro estudiantes bilingües inscritos en cursos elementales de español como lengua extranjera. Conforme con lo que sugiere la literatura, encuentro que estos estudiantes tienen una opinión pobre de sus propias habilidades en castellano y una fuerte preferencia por la variedad estándar. Finalmente, con la esperanza de combatir estas ideas y tender un puente entre los hablantes bilingües y los aprendices de lengua extranjera, contemplo cómo se puedan incluir estudiantes de trayectorias diversas en la misma aula.

Palabras clave: español, lengua de herencia, ideologías lingüísticas, idoneidad, racialización 


\begin{abstract}
Résumé
L'enseignement de la langue espagnole dans l'enseignement supérieur aux ÉtatsUnis de nos jours est généralement divisé sur les cours de la langue étrangère' pour les débutants et les cours de la 'langue d'héritage' pour les étudiants Hispaniques/Latinx avec un peu de connaissance de la langue. Cependant, les étudiants 'héritages' sont un groupe linguistiquement divers et ils sont souvent inscrits dans les universités où les cours de la 'langue héritage' ne sont pas proposés. Peu de recherche jusqu'à ce jour a étudié les étudiants 'héritages' inscrits dans les cours de 'langues étrangères'. Pour cette étude j'ai dirigé des entretiens demi-structurés à explorer les caractéristiques affectifs et idéologiques des étudiants bilingues inscrits dans les cours d'espagnol novice. Comme suggère la littérature, je trouve que ces étudiants ont généralement une piètre opinion de leurs performances en espagnol et une préférence pour l'espagnol standard. Finalement, dans l'espoir de combattre ces notions et réduire l'écart entre les étudiants héritages et les étudiants débutants, je réfléchis sur les moyens par lesquels les étudiants de milieux divers peuvent être inclus dans la même salle de classe.
\end{abstract}

Mots clés: l'espagnol, langues d'héritage, idéologie de la langue, justesse, racialisation

\title{
Introduction
}

In this article I consider questions of language-learning motivation, access to language education, language ideologies and attitudes, and pedagogical approaches as concerns bilingual/heritage ${ }^{1}$ speakers enrolled in Spanish as a 'foreign' or 'second' language classes. This study is based on the qualitative analysis of semi-structured interviews with four New York Latinx students of varying ages, national backgrounds, and proficiencies in Spanish, enrolled in an elementary Spanish course at Brooklyn College, a large public university in New York City. This article illuminates some important issues for language educators to consider, including how to encourage positive understandings of bilingual varieties of Spanish and how to combat ideologies that hierarchize named languages and varieties and demean bilingual students' native varieties as inadequate. The final consideration is how to approach teaching when Spanish-English bilinguals and novice learners are placed together in the same classes.

\section{Context}

This study grew out of a $\mathrm{PhD}$ course in Global Language Policies in Education at the Graduate Center (GC) of the City University of New York (CUNY). The course was selected to participate in the Futures Initiative (FI), a GC-based program that reaches throughout CUNY and advocates greater equity and innovation in higher education. The Academic Year 2015-2016 theme is 
Diversity, Access, and Equity Across the Curriculum. In this spirit, the present study examines questions of access to language education and pedagogical approaches in the teaching of Spanish to students of diverse linguistic backgrounds, particularly contemplating the distinction between students with previous exposure to Spanish and novice learners. Interviews were completed with four bilingual students enrolled in two elementary Spanish courses taught by the author at Brooklyn College, CUNY.

\section{The bilingual student}

The profile of the bilingual student for the purposes of this study is a college student born in the US to parents or grandparents who immigrated from a primarily Spanish-speaking country or territory and who has to some degree been exposed to Spanish at home or in the community. While second- and third-generation students (especially the former) often have some command of Spanish linguistic features, research indicates that, having been educated primarily in English, they tend to feel that their Spanish is incomplete or imperfect, especially their formal Spanish (Cummins, 2005; Leeman, 2012; Potowski, 2002; Valdés, González, García, \& Márquez, 2003). They also have to contend with widespread linguistic ideologies that devalue their ways of using language, from their English (often working-class urban varieties or ethnolects perceived to be 'contaminated' by the ethnic language) to their Spanish (often non-standard rural or workingclass urban varieties from their countries of origin) and, especially, their translanguaging practices (Flores \& Rosa, 2015; García, 2009; Leeman, 2005, 2012). They also often have to deal with affective barriers to acquisition of the standard variety. In the following paragraphs I will consider the linguistic and language ideological characteristics of these students.

\section{The bilingual student: Linguistic characteristics}

Linguistically, as in other regards, bilingual students are far from a homogeneous group; their proficiency in Spanish ranges widely along a "continuum of bilingualism" (Silva-Corvalán, 2004, quoted in Lynch, 2008), from quite limited (similar to or indistinguishable from students not of Latinx origin), to those with good spoken proficiency in everyday language but limited abilities to read and write the standard language, to those who control educated registers of both the spoken and written language (Kondo-Brown, 2005; Lynch, 2008). Those students with strong command of written and formal varieties of the language are the minority, however; having been 
schooled mostly in English, these students have often had little instruction in Spanish and struggle with reading, writing, and formal speech. These issues are often exacerbated by the socioeconomic difficulties they face as members of a minority group, including racial and linguistic discrimination (García \& Mason, 2009).

\section{The bilingual student: Ideologies of language}

The literature shows that bilingual students who have been educated mostly in English tend to believe that their Spanish is 'broken' or 'improper' (Leeman, 2012). They also live in environments where their home varieties are stigmatized, either as a result of their national origin or the socioeconomic status of their families. They tend to believe that middle-class, monolingual Spanish spoken in Latin America or Spain is better or more 'pure' than their own varieties.

This can lead to affective barriers to the smooth expansion of their linguistic repertoires. Being told by even the most tactful, well-intentioned professor that the way they speak is not 'correct,' or even just 'inappropriate' for certain situations, can demoralize even the most motivated student. Being told that what they speak is not 'real' Spanish, in the case of calques and other features of contact, can threaten a speaker's identity as a Spanish speaker or member of her national origin community. This sense of disaffection can be exacerbated when students who have no previous knowledge of Spanish seem to have an easier time learning standard Spanish, given that they do not have to change any 'bad' habits.

\section{Spanish language teaching in US tertiary education}

Spanish language courses in US tertiary education, like most courses in languages other than English (LOTEs), have traditionally been tailored to students born and raised in the United States in non-Spanish-speaking homes (Lacorte, 2013) and focused on standard form(s) of the language. These courses tend to be structured around the acquisition of progressively more complex sets of grammatical forms, which have been standardized to reflect not actual usage, but the forms deemed most 'correct,' generally based on the language of a particular social group at a particular time and place, within which variation and diversity have been minimized to the extent possible. The history of language standardization and the ideologies surrounding it have been amply theorized elsewhere (e.g., Bourdieu, Thompson, \& Raymond, 2003; Milroy \& Milroy, 2012). 
Here, I am mainly concerned with the erasure of linguistic diversity and the obviation of bi/multilingual practices.

Teaching a standard language involves, by definition, the erasure, or at least minimization, of sociolinguistic variation, and often even of much geographical variation. Thus, phonology, lexicon, or syntax that diverge from the idealized standard are omitted from foreign language texts entirely. The main exceptions in Spanish, called a 'pluricentric' language by the institutions $^{2}$ that regulate its use, are tolerance of some geographical lexical variation and a few broad dialectal differences in pronunciation, pronoun use, and verb conjugations deemed acceptable variations within the standard.

Spanish has also traditionally been understood not as a language present in the community where US learners live, but as an abstract, idealized set of grammatical forms, used by idealized homogeneous foreign populations. $\mathrm{Bi} /$ multilingual practices receive even less attention in Spanish-language textbooks than does sociolinguistic variation. Textbooks still tend to present Spanish speakers as monolinguals living in monolingual societies; languages other than Spanish within majority Spanish-speaking societies are generally ignored, as is the presence of tens of millions of Spanish speakers in the United States. US bilingualism beyond the second generation and multilingual practices such as translanguaging are rarely mentioned, and certainly not portrayed to foreign-language learners as legitimate ways of using language or recommended as strategies to use in language acquisition.

Finally, since the advent of communicative methods, recourse to English (or other languages students already speak well), any sort of comparative linguistic methodology, and explicit grammar instruction have generally been discouraged in language teaching. The mainstream mantra has been that acquisition can only take place in the L2, that grammatical explanations or explicit teaching of metalinguistic information have no effect on outcomes, and that any recourse to the L1 represents a failure of the language teacher to communicate the concepts using the L2. This is the result of a maximalist understanding of the input and monitor hypotheses (Krashen, 1982, 1985), which posit that acquisition only takes place when the learner makes sense of comprehensible input in the L2. While in reality these concepts are more complicated than this, and there are competing theories, many language teachers continue to believe that in-class use of any language besides the one being taught and even explicit grammatical instruction are not valid strategies in teaching languages. This is despite more recent 
research that indicates learner's other languages can be useful and effective tools to scaffold the learning of new languages (McMillan \& Rivers, 2011; Turnbull \& Dailey-O’Cain, 2009).

\section{Spanish at Brooklyn College}

The following section aims to provide a brief overview of the institutional conditions for Spanish language teaching and learning at Brooklyn College (BC), the site of the present study. BC is a senior college within the City University of New York system, located in a diverse area of Brooklyn, a borough of New York City. The undergraduate population in Fall 2015 was 14,207. $\mathrm{BC}$ is somewhat whiter and less Latinx than the rest of the CUNY system $(40.9 \%$ white vs. $26.4 \%$ for the system as a whole; $14.2 \%$ Latinx vs. $29.1 \%$ for all of CUNY) (CUNY Office of Institutional Research and Assessment, 2015).

At BC, Spanish is taught by the Department of Modern Languages and Literatures. The elementary language program is three semesters long. There are 'Heritage' Spanish language courses listed in the catalog, although, as will be detailed below, these courses have not been offered for some time. The lack of heritage courses is an important element of this article, and deserves some contextualization.

Across the CUNY system, language class enrollments were adversely impacted by the implementation of a hotly debated system-wide revamping of the core curriculum (an initiative known as Pathways), implemented at BC in Fall 2013. Among many other changes, Pathways relaxed language requirements and reduced LOTEs to one option among many within a 'flexible core'. Drops in language enrollments were especially steep beyond the first semester. Between Fall 2012 and Fall 2015, offerings of Spanish I dropped from six to five sections; Spanish II dropped from six to two; and Spanish III from seven to three, with enrollments often hovering around ten students per section in this, the final language course in the cycle.

Heritage Spanish courses are listed as offered by the Department of Modern Languages and Literatures, but have not been taught in at least the last three academic years, as far back as the College maintains schedules of classes on its website. This is presumably due to resource constraints and a choice to focus on the traditional core mission of university language departments, teaching learners who do not speak the language at home or in the community. Without heritage courses, in the anecdotal experience of the author, bilingual students enroll in Spanish I at a rate of approximately $20-25 \%$ of all enrollees. 


\section{Research Questions}

These circumstances create a dilemma for the department and individual instructors: how are instructors best to serve these students? Course descriptions, written with the assumption that heritage courses would be offered, state that heritage students are barred from enrolling in basic Spanish language courses. Should instructors enforce this rule even though heritage courses are not in fact offered? Should bilingual students be obliged to take courses in other languages or more advanced Spanish language or literature classes, even if they are insecure in the fundamentals of their Spanish? If they remain in elementary classes, how should instructors serve their unique affective and linguistic needs within the framework of a course that is (at best) not designed with them in mind and (at worst) actively marginalizes their experiences and the linguistic repertoires they bring to the table? How can instructors structure their courses when they have such a diversity of linguistic abilities in the same classroom?

I will focus my analysis in this study on three main research questions:

1. What are students' affective relationships to the linguistic codes they use? Specifically, what linguistic ideologies do Spanish-English bilingual students have about Spanish, especially the non-standard, bi/multilingual varieties they speak?

2. What motivations do these students claim for taking elementary Spanish-language classes?

3. How can language instructors improve their approach to language education and classroom practices to better serve students from a diversity of language backgrounds in the same pedagogical space?

\section{Bilingual Students in This Study}

For the present study I interviewed four bilingual students enrolled in Spanish 1010 (a first-semester Spanish course) at Brooklyn College. Interviews were conducted in English and recorded using a digital voice recorder. They ranged from 25 minutes to almost an hour. I was the instructor of both sections from which participants were selected, a reality which will be addressed in the analysis.

The four students featured here are a diverse group, including different national origins, socioeconomic classes, skin tones, genders, and ages. A major factor in common for all was the fact that they spoke English well enough as young children to test out of bilingual programs (at the latest, by the second grade) and went through nearly the entire educational system in English, 
with minimal instruction in Spanish. All four participants could thus be described as Englishdominant with varying levels of exposure to Spanish. While this may have spared them some of the negative consequences of being pigeonholed as long-term ELLs (García, 2009), it also resulted in a lack of instruction in Spanish or exposure to formal, academic varieties of the language.

Before discussing the results that emerged from the interviews, I will provide some details about each participant. Names have been replaced with pseudonyms to protect participants' privacy.

\section{Claudia}

'Claudia,' 19, is a sophomore (second-year BC student). Both her parents immigrated to New York as young adults, her mother from Colombia and her father from the Dominican Republic (DR). Her parents split when she was around six; today, she lives with her mother, grandmother, and other maternal relatives. She reports speaking mostly Spanish at home, especially with her grandmother, whose English is limited. She feels she mostly speaks Spanish with a Colombian accent, but reports switching to a Dominican accent when she is with her Dominican family or friends. Claudia recalls learning the basics of reading and writing Spanish in a bilingual first grade class, but as she then switched to a monolingual English class, she did not have any further instruction in Spanish until high school, when she took two years of basic Spanish 'foreign language' courses.

\section{Karolina}

'Karolina,' 18, is currently a freshman (first-year student) at BC, considering majoring in bilingual education. Her mother, still a monolingual Spanish speaker, immigrated from the Dominican Republic as an adult, while her bilingual father, also Dominican, came with his family as a baby. She speaks mostly English with her father and Spanish with her mother. She was in bilingual education in pre-K but did not take Spanish again until high school, when she took one year of regular Spanish and one year of a heritage course. She also works as a bilingual aide at a school for children with autism. 


\section{Luis}

'Luis,' 18, is a freshman at $\mathrm{BC}$ and plans to eventually transfer elsewhere to study civil engineering. He was born in New York City to Dominican parents and raised in Brooklyn. He reports speaking a mix of English and Spanish at home, today using more English than Spanish. Despite speaking mostly English, he speaks some Spanish every day, with his parents, his extended family, including cousins around his age, or friends. He had not received any instruction in Spanish before this class, although he took some Italian in middle school and three years of Latin in high school.

\section{James}

'James,' 30, is currently enrolled full-time at Brooklyn College majoring in Education, with the goal of becoming a physical education teacher and basketball coach. He is the grandson of Puerto Rican migrants. Until the age of six, he lived with both parents and his maternal grandparents. $\mathrm{He}$ learned Spanish and English simultaneously, as his grandparents spoke mostly Spanish, although he reports always feeling more fluent in English, as his mother spoke mostly English with him. Around the time he started school (in English), his grandmother died, his grandfather moved away, and his parents split up, at which point he stopped speaking Spanish regularly and transitioned to being essentially monolingual in English, losing most of his expressive abilities in Spanish. While he never studied the language before taking my course, James picked up colloquial Spanish in the workplace over the last ten years, where he deals mostly with Spanishspeaking clients. Today he can hold a conversation in Spanish, but mostly resembles an L2 speaker, especially in terms of his grammatical accuracy.

\section{Analysis \& Discussion}

\section{RQ 1: Students' language ideologies regarding Spanish}

It was clear from the interviews that students' beliefs about different varieties of Spanish were a major factor influencing their approach to the course. This includes varieties identified with the students' national origins and the ways in which their Spanish reflects their bilingualism in English.

All students understood their Spanish to be deficient in some way. They reflected several ideologies previously identified in the literature. One of the most prominent is a bias in favor of 
the standard language (Lippi-Green, 1997) and the belief that the standard is internally consistent and superior to both non-standard monolingual varieties and contact varieties. They also believe that speaking the standard will make it easier to communicate with speakers from diverse backgrounds.

Students regularly expressed a belief in the incompleteness or inferiority of bilingual Spanish. Claudia, for example, feels that monolingual Spanish speakers in Latin America view US Spanish as different from their varieties in a way that delegitimizes it. At the same time, Claudia feels that Spanish speakers in the US are more dynamic, 'modern' and flexible, making use of the language in more creative ways:

Claudia: Over there, whenever we go and say something that's not really familiar to them, they look at us like ... "Why are you guys pronouncing it that way? It's not that way, it's the other way that you say it." I feel like in Colombia that was my experience ... I feel like they stick to what they were taught when they were little. Here, we mix it up. We use different terms to describe stuff. When we go over there ... They're not really familiar with it.

Michael: Did it seem like the way that you were speaking was not legitimate to them or they just weren't familiar with it?

Claudia: I think both. They didn't think it was legitimate and they didn't really understand what we were talking about.

Luis recounted a similar experience in which contact varieties of Spanish, influenced by English, were rejected or not understood by his family in the DR. This points to tensions introduced by the sociolinguistic situation in the Spanish-speaking world, which has its own internal hierarchization and monolingual bias. Interesting similarities exist between this and the situation in the Arabic-speaking world (see Love, this volume), despite the fact that virtually all varieties of Spanish are mutually intelligible, unlike the differences between Arabic vernaculars.

Indeed, all three Dominican participants pointed to the hierarchization of varieties of Spanish. While the issue was couched in terms of 'appropriateness' and framed as cultural rather than linguistic, the Dominican participants expressed strong beliefs that certain varieties are appropriate for certain situations, and they consistently characterized Dominican Spanish as not 'proper' or 'correct' and therefore not appropriate for all situations. Claudia, who is of mixed 
Dominican and Colombian heritage, reports switching between her 'accents' depending on her interlocutor and the situation. She related that she would only use her Dominican voice with other Dominicans she knew intimately, not with higher-status people:

Claudia: I feel like speaking in my Dominican accent would be appropriate to speak with my Dominican family or even my Dominican friends. I feel like that's okay, but speaking to a president or even a professor, I don't feel like it sounds correctly. That was just the way I was raised. You have to speak this way. You can't speak like that.

Luis reported trying to change his Spanish based on things he's learned in class, even with his family. He has also tried to correct others, in the hope that his new, more 'appropriate' Spanish will spread through social pressure:

Luis: I definitely want to get into the habit of just learning how to speak in that manner all the time, because not only will I be able to enhance how fluent I'm speaking the language, but also being able to help my family and whoever else ... I think that by them saying, "Okay, that sounds a little more appropriate," maybe they should start using that as well. It just, I feel like it would make it easier to communicate with people no matter what background they have.

These statements point to a belief that participants' ways of speaking are inferior to the standard. Contradicting the notion that students might reject the standard as inauthentic or threatening (Helmer, 2013), James dismisses the importance of local authenticity and embraces the pan-Hispanic ideology of unity in diversity (del Valle, 2009):

James: I think Spanish is Spanish, and if you know how to speak it, and enunciate the word properly, and learn how the subject, pronoun, verb, and the placement of these grammatical components, I think that it shouldn't matter. I just think that Spanish should just be Spanish. I understand that everybody has different words for different things, but I think that's all interchangeable. I'm fine with learning it from the textbook.

On the whole, we see that these bilingual students have a high opinion of standard or academic Spanish, even though it's not the variety they most control, to such an extent that they are ready to abandon the ways they have grown up speaking in order to acquire the status that the 'textbook standard' version of the language seems to afford. This should not be surprising, given 
the rest of the sociolinguistic literature, especially since the students participating in this study are upwardly mobile and academically inclined. Nonetheless, as instructors, with the knowledge of the deleterious effects of such ideologies in society as a whole, should we simply facilitate their acquisition of the standard, their stated goal, without challenging them to think critically about the ideas that they already have about local and non-standard varieties of Spanish?

\section{RQ2: Reasons for taking Spanish I}

The ideologies expressed above clearly had an effect on students' decision to take a basic Spanish course, and are reflected in their responses to questions about the topic. I believe the institutional context (detailed in the section "Spanish at Brooklyn College" above) also provides a good deal of explanation. However, the interviews gave a more detailed picture of students' own rationale (or rationalizations) for taking Spanish. In discussing their reasons for taking a basic Spanish course, student participants cited their restricted linguistic repertoires in Spanish, their insecurity with the formal aspects of language or understanding grammar, their lack of practice with reading and writing, and generally, a perceived need to improve their Spanish.

Luis feels that his Spanish is imperfect or incomplete and needs reinforcement through formal study. He points to grammar explanation as a positive element of the course, in that it gives him more confidence that he is speaking in a way that he believes will be respected by others.

Luis: I myself don't understand all the grammar that goes into [Spanish]. I may say something that I may feel like it's correct until my family they might make jokes because it doesn't come out exactly how it's supposed to. That's why I'm getting into the learning of it now. [...] It's actually why I chose the class so that I can be introduced more to the language, make sure that I'm speaking properly. I want to be able to hold down a conversation with someone in Spanish and not trip over my words or have to think about something.

Identity questions also figure into some participants' explanations for taking the course. James, despite showing the least consistency in his linguistic performance, places much importance on speaking the language well as a sign of identity: 
James: I'm taking this class because I'm aware that I'm American. I was born and raised here, but I also still want to hold on to some of my heritage, so I can pass it on to my children. The fact is grandparents they're starting to die away. For me that is very important for me to learn how to speak the language and also to speak it correctly. I've also come in contact with individuals who speak the language who find it offensive if you don't speak the language properly. So, for me it's very important to speak the language, and speak it properly, and more importantly, to learn more about the heritage, what you come from and your bloodlines.

Some bilingual students are probably taking Spanish because they think it will afford them a high grade and a boost to their Grade Point Average (GPA) without much effort. Given the lack of heritage Spanish courses, I can hardly fault them for making this choice. As could be predicted from the context of the interviews, none of the students expressly told me (their instructor) that "getting an easy " $\mathrm{A}$ "" was their primary motivation for taking the course, although one came close. And indeed, while I do not discount this as one factor, I don't see it as the primary motivating feature. Students provided well-articulated and nuanced rationales for taking Spanish I:

Karolina: I chose [the course] because I knew since I already know the language it wouldn't be hard learning a new language. And also just to perfect the way I speak. Just because the way I speak Spanish is more of the way I grew up versus learning the proper way of saying things. Here I learn to perfect the dialect I guess.

Karolina continued her explanation of taking Spanish I by identifying what she felt were the shortcomings of her heritage Spanish course in high school:

Karolina: [In heritage courses in high school] you're [just] reading books and writing papers. It's not necessarily, 'Oh, you have to write - this makes sense this way.' It was more if I did a mistake on my paper that's how I was corrected, versus getting a breakdown of how to speak it.

Interestingly, the heritage course she took in high school did not provide the level of explicit feedback and grammar breakdown that Karolina would have liked or needed to feel secure. The metalinguistic information common in Spanish courses aimed at first-time learners was thus seen 
by this participant, as well as others, not as a detriment or a waste of time, but as valuable content that she was missing in her linguistic education.

Another common theme was acquiring a Spanish that was more akin to that spoken in Hispanophone-majority countries, or at least the standard variety of the language detailed in the textbook, which was believed to be both more 'appropriate' and more 'universal' than their local varieties. When indicating what they hoped to get out of the course, participants expressed a desire to learn 'universal,' 'correct' or 'proper' Spanish. This idealized variety was contrasted with non-standard monolingual varieties spoken by certain groups (variously identified as the uneducated, all Dominicans, Dominicans from the campos, people from the 'street,' etc.), as well as with ways of speaking influenced by contact with English (use of terms like 'yarda' for 'backyard,' instead of 'patio').

Luis: [We]'re so used to just speaking the slang that we do or just saying things how we feel comfortable. It's not the same thing as when you actually go out into the world, you meet people from different countries, or speaking as I would say proper Spanish. If I were to go to Spain now I would be able to communicate, getting more into the course; I would be able to have a conversation with someone from Spain without getting confused or confusing them. [...] I feel like overall now learning Spanish over here I'm getting a more universal way of speaking Spanish so when I go somewhere else it would, I feel, be much easier to communicate.

I also asked participants if they thought that the material presented in Spanish I was too easy or basic. I have to assume that answers were influenced by the fact that I, the interviewer, was also the participants' instructor. Nonetheless, I believe their answers to point to genuine reasons for taking Spanish I:

Claudia: I don't feel like it's ever basic... even today with the 'los' and 'las' ${ }^{3}$ I feel like I always forget how to work on the grammar part of Spanish.

Overall, students felt they were learning new content even within a course not intended for bilinguals or native/heritage speakers. Some of this may be rationalization, but a key element of this appears to be the metalinguistic knowledge that the type of course offers. It is clear that formal instruction and metalinguistic understanding are not required to acquire a language, be it 
the dominant community language or a minority language. However, for a language such as Spanish, spoken over a wide geographical territory, with a centuries-old and highly developed written tradition, wide sociolinguistic and geographical variation, and highly differentiated oral and written, formal and informal registers, formal study is generally necessary to acquire a repertoire deemed acceptable for professional purposes. The students in this study are keenly aware of their lack of formal study of the language, as well as the ways the Spanishes they acquired at home or in the community are different from prestige varieties. They are anxious to learn more; just what they expect to learn and how that process is understood is another question, perhaps the most important one we face as instructors.

\section{RQ3: Effectively instructing bilinguals and L2 learners in the same classroom}

Many foreign language instructors assume that bilingual students do not belong in their classrooms, at least if they have mastered the language beyond the level being taught. They often require such students to take another course, be it a heritage course or a higher-level Spanish class. However, based on the findings of this project, especially when heritage classes are not an option, I am hesitant to take such an approach. I believe that our goal should be to reach the optimal learning outcomes for all students, both heritage and traditional L2 learners, and I believe it is possible to do so within an inclusive language classroom when conditions require it.

In reality, the ideal setting for most of these students would likely be a heritage course appropriate for their linguistic performance, where the type of language instruction would be targeted at building on their existing skills and where their ideological and affective needs could also be addressed head-on in a supportive space. However, in a climate wherein 'austerity' limits course offerings to the bare essentials, and those essentials have been determined to be courses that serve novice learners, how can instructors construct the best approach that will meet the stated goals of their courses and the needs of the majority of students (teaching Spanish to L2 learners) while also meeting the needs of their bilingual students?

In light of the above findings, I propose that instructors should find new ways to engage with a broad spectrum of abilities and experiences within the same classroom. We should be designing activities that meet several goals:

1. Embrace the fact that Spanish is a daily reality and a second language in the United States, not a foreign one. The past few decades have seen the spread of Spanish and Spanish- 
speakers beyond their traditional geographical strongholds in the border states and major urban centers to places of high visibility throughout the 50 States. In New York this is not new, but the perception is still often that Spanish is not a local reality, but a language spoken either in foreign countries or by immigrants. Highlighting the role that Spanish-based linguistic repertoires play in the lives of Americans of the second and third generation, as well as the opportunities, both social and economic, that Spanish can open up, can increase motivation among heritage speakers and FL learners alike. We also need to start accepting US Spanish as a legitimate variety, taking note of the variation unique to the US on the same terms we do for varieties spoken in Spanishmajority countries (Otheguy, 2008; Otheguy \& Stern, 2011).

2. Embrace, not discourage, translanguaging and multilingual practices in the classroom. The reality of Spanish use, both in the United States and in Spanish-majority countries, is no longer a monolingual one, if indeed it ever was. Continuing to insist on a monolingual model in the classroom not only results in an othering of the target language and its speakers; it also fails to reflect the ways in which bilingual speakers experience language. Furthermore, it fails to take advantage of some of the most important language-learning tools that monolinguals and bilinguals alike possess, namely, the ability to build connections between codes and construct their own semantic networks and theories of grammaticality based upon their existing knowledge.

Following Cummins (2005), I support making use of multilingual connections and crosslinguistic comparisons in the foreign-language classroom (including scaffolding content knowledge with English discussion). This would involve regularly requesting input from bilingual students on usage and vocabulary, recognizing them as linguistic authorities and turning them into local-language experts in the classroom, in addition to their role as students expanding their own repertoires to include (properly contextualized) standard features. Allowing students to use English and employ metalinguistic knowledge and cross-linguistic comparison does not imply a return to grammar-translation methods of foreign-language teaching and learning; rather, it involves facilitating acquisition through the construction of knowledge and skills by students, using tools that they already have at their disposal, namely, the diversity of linguistic experiences present in the classroom and their multilingual environment. Tasks would call direct attention to oral translanguaging practices and multilingual texts, emphasizing the usefulness of the full spectrum of multilingual competencies. 
This approach would require instructors to rethink the expected outcomes of language courses. Instead of imagining that we will be producing a parallel monolingual or 'native-like' Spanish speaker within novice Spanish learners, or teaching the bilingual to speak exactly like a monolingual, we would have to expect that we would be producing multilingual, multicompetent speakers with repertoires that reflect their experiences and needs. All successful students in this model would gain new abilities in the language as well as an understanding of how it works, a goal they all apparently share; they would likewise develop the ability to recognize different ways of using their languages, and understand the consequences of making value judgments about language use, a goal that goes hand in hand with the next point.

3. Promote critical language awareness. Question 'appropriateness' as the goal for heritage language education. Challenge the structures and ideologies that designate nonhegemonic forms of language as deficient. My students provide ample evidence that bilinguals come to the classroom with negative understandings of bi/multilingual and other non-conforming ways of using language. In the heritage language education field, the (in)appropriateness of US bilingual varieties of Spanish for certain contexts is often the rationale for teaching students new registers or eliminating 'non-standard' features from their language. Several recent articles (Flores \& Rosa, 2015; Showstack, 2010) have questioned the appropriateness of 'appropriateness' as the basis of heritage language education.

For these authors, just defining some forms of language as appropriate for certain contexts and others as less than does not serve speakers who use and will continue to use these forms. Instead, it reinforces the ideologies, structures and practices that mark bi/multilingual speakers and their language as 'inappropriate' in the first place. Flores and Rosa (2015) point out that Spanish speakers in the US are a racialized minority, and the real problem with raciolinguistic discrimination lies not in the way racialized speakers use language, but in the ways their interlocutors interpret their languaging (p. 152). Indeed, even when they speak in ways that are not different from their white peers in any quantifiable way, Latinos and other minorities are frequently perceived as having an 'accent' (p. 152). The problem is not with the 'speaking subject' but the 'listening subject' (p. 152) who hears an accent where none is present, racializing the speaker. Teaching appropriateness is useless from this perspective, as even when speakers use the most 'appropriate' forms, they will continue to be perceived as deficient based upon their identities as racialized minorities: Latinxs, blacks, Dominicans, bilinguals, etc. Without a "critical 
heteroglossic perspective" (p. 154) that acknowledges and challenges the linguistic ideologies of the listening subject, no manner of 'appropriate' languaging on the part of the speaking subject will be enough to grant them the linguistic legitimacy they seek. Showstack (2010) provides a framework, used by both heritage and second-language learners, in which real-world projects based in the local community can invite students to engage critically with the variety of language around them and the value judgments about language and speaking subjects that manifest in commonly held linguistic ideologies.

4. Utilize the variety of linguistic abilities and strengths students bring to the classroom through constructivist group projects or pair work. This final step is perhaps the most challenging from a pedagogical perspective, especially in elementary courses where students are pressed for time, perhaps not deeply invested, and often still reaching to grasp basic linguistic concepts and a working vocabulary. This could involve a project similar to that outlined in Showstack (2010), in which bilinguals and novice learners participated in a community-based project exploring the place of Spanish in the local community, perhaps simplified to focus on the kinds of linguistic features L2 students are still acquiring, but which are also relevant to bilingual students. In the past, I have offered extra credit options that encouraged students to engage with multilingual texts (signs, labels, etc.) and identify differences in tone or content for English and Spanish speakers. Another option I have offered required students to record themselves having a real-world conversation in Spanish, then analyze the linguistic features both parties used and reflect on the effectiveness of the interaction as a communicative event. Either of these activities, as well as many others, could be developed to include additional elements of critical language awareness and adapted for pairs or small groups combining bilingual and L2 learners.

\section{Conclusions}

I hope to have outlined some of the issues instructors in my position grapple with on a daily basis and provided food for thought for instructors in a similar position and other interested observers. Much of the work on heritage language education focuses on the development of biliteracy in bilingual speakers (Hornberger, 2005; Hornberger \& Link, 2012). While I agree that this is an important goal, and indeed improving writing is an objective that participants identified as one of their own goals in taking Spanish, it is becoming clear that teaching students to read complex texts and to write the standard variety is not enough, and will do little to combat the negative 
ideas that students themselves and others in the community have about their ways of languaging. Nor is it enough to teach students that certain registers or varieties of the language are 'appropriate' for certain situations while others are not. When speakers find it difficult to change their linguistic practices, or their efforts - however effective- are not recognized, the end result is encouraging abandonment of the language, or at least formal study of it, which may have knock-on effects in students' educational and working lives. We must find ways to encourage students to think critically about language variation and multilingualism, from its origins to its effects on speakers. These lessons are equally valid and urgent for both Spanish-English bilinguals and their novice learner classmates.

Despite the institutional hurdles to completely rethinking curricula, the core of the recommendations above could be implemented individually by instructors without redefining major goals or designing new courses. They could be applied anywhere the language is taught, whether heritage courses are offered or not, although they would probably be most useful where heritage courses are not an option. While the challenges of such an undertaking are great, the potential rewards are greater, in the satisfaction and excitement of piloting new techniques and leading a more dynamic and engaging classroom. Increasing critical language awareness and helping all students to understand the value of multilingualism are certainly goals worth fighting for.

\section{Notes}

1. For the purposes of this paper, the term 'bilingual' will be preferred over 'native speaker' and 'heritage speaker' (or learner), except when 'heritage' is the term used in official documentations or by participants. I avoid the concept of the 'native speaker' as a linguistically untenable construct, which is particularly difficult to operationalize in bi/multilingual contexts. I try to avoid 'heritage' when possible as it can delegitimize these speakers by reinforcing a monolingual bias. For a more complete critique of the concepts of native and heritage speakers, see Love (this volume).

2. Primarily the Real Academia Española de la Lengua and other national academies, the Asociación de Academias de la Lengua Española, along with the Instituto Cervantes, Fundéu $B B V A$ and other institutions dedicated to the promotion of the Spanish language; see del Valle (2009).

3. The grammatical feature in focus that day was direct object pronouns. 


\section{References}

Bourdieu, P., Thompson, J. B., \& Raymond, G. (2003). Language and symbolic power (Reprinted). Cambridge: Harvard Univ. Press.

Cummins, J. (2005). A Proposal for Action: Strategies for Recognizing Heritage Language Competence as a Learning Resource within the Mainstream Classroom. The Modern Language Journal, 89(4), 585-592.

CUNY Office of Institutional Research and Assessment (2015, April 21). Total Enrollment by Race/Ethnicity and College: Percentages. Retrieved from https://www.cuny.edu/irdatabook/rpts2_AY_current/ENRL_0015_RACE_TOT_PCT.rpt.p df

del Valle, J. (2009). Total Spanish: The Politics of a Pan-Hispanic Grammar. PMLA, 124(3), 880886. http://doi.org/10.2307/25614331

Flores, N., \& Rosa, J. (2015). Undoing Appropriateness: Raciolinguistic Ideologies and Language Diversity in Education. Harvard Educational Review, 85(2), 149-171. http://doi.org/10.17763/0017-8055.85.2.149

García, O. (2009). Racializing the language practices of US Latinos: Impact on their education. In J. Cobas, J. Feagin, \& J. Duany (Eds.), How the United States racializes Latinos: White hegemony and its consequences (pp. 101-115).

García, O., \& Mason, L. (2009). Where in the world is US Spanish? Creating a space of opportunity for US Latinos. In W. Harbert, S. McConnell-Ginet, A. Miller, \& J. Whitman (Eds.), Language and poverty (pp. 78-101). Bristol, UK; Buffalo: Multilingual Matters.

Helmer, K. A. (2013). A Twice-Told Tale: Voices of Resistance in a Borderlands Spanish Heritage Language Class. Anthropology \& Education Quarterly, 44(3), 269-285. http://doi.org/10.1111/aeq.12025

Hornberger, N. H. (2005). Opening and Filling up Implementational and Ideological Spaces in Heritage Language Education. The Modern Language Journal, 89(4), 605-609.

Hornberger, N. H., \& Link, H. (2012). Translanguaging and transnational literacies in multilingual classrooms: A biliteracy lens. International Journal of Bilingual Education and Bilingualism, 15(3), 261-278. http://doi.org/10.1080/13670050.2012.658016

Kondo-Brown, K. (2005). Differences in Language Skills: Heritage Language Learner Subgroups and Foreign Language Learners. The Modern Language Journal, 89(4), 563-581. http://doi.org/10.1111/j.1540-4781.2005.00330.x

Krashen, S. (1982). Principles and practice in second language acquisition. London: Pergamon Press : [distributor] Elsevier Books Customer Services.

Krashen, S. (1985). Second language acquisition and second language learning (Reprinted). Oxford: Pergamon.

Lacorte, M. (2013). Sociopolitical and institutional conditions for teaching Spanish as a L2 in US universities. Spanish in Context, 10(3), 331-349. http://doi.org/10.1075/sic.10.3.01lac

Leeman, J. (2005). Engaging Critical Pedagogy: Spanish for Native Speakers. Foreign Language Annals, 38(1), 35-45. http://doi.org/10.1111/j.1944-9720.2005.tb02451.x

Leeman, J. (2012). Investigating language ideologies in Spanish as a heritage language. Spanish as a Heritage Language in the United States: The State of the Field, 43-59.

Lippi-Green, R. (1997). English with an accent: language, ideology, and discrimination in the United States. London; New York: Routledge. 
Lynch, A. (2008). The Linguistic Similarities of Spanish Heritage and Second Language Learners. Foreign Language Annals, 41(2), 252-381. http://doi.org/10.1111/j.19449720.2008.tb03292.x

McMillan, B. A., \& Rivers, D. J. (2011). The practice of policy: Teacher attitudes toward "English only." System, 39(2), 251-263. http://doi.org/10.1016/j.system.2011.04.011

Milroy, J., \& Milroy, L. (2012). Authority in Language: Investigating Standard English. Routledge.

Otheguy, R. (2008). Affirming Differences, Valuing Variation and Dismissing Dialects in Modern Linguistics. Studies in Hispanic and Lusophone Linguistics, 1(1), 223-233. http://doi.org/10.1515/shll-2008-1013

Otheguy, R., \& Stern, N. (2011). On so-called Spanglish. International Journal of Bilingualism, 15(1), 85-100. http://doi.org/10.1177/1367006910379298

Potowski, K. (2002). Experiences of Spanish Heritage Speakers in University Foreign Language Courses and Implications for Teacher Training. ADFL BULLETIN, 35-42. http://doi.org/10.1632/adfl.33.3.35

Showstack, R. (2010). Going Beyond "Appropriateness": Foreign and Heritage Language Students Explore Language Use in Society. In Proceedings of Intercultural Competence Conference (Vol. 1, pp. 358-377). Retrieved from http://cercll.arizona.edu/_media/development/conferences/2010_icc/showstack.pdf

Turnbull, M., \& Dailey-O'Cain, J. (Eds.). (2009). First language use in second and foreign language learning (Vol. 44). Bristol, UK ; Buffalo [N.Y.]: Multilingual Matters.

Valdés, G., González, S. V., García, D. L., \& Márquez, P. (2003). Language Ideology: The Case of Spanish in Departments of Foreign Languages. Anthropology \& Education Quarterly, 34(1), 3-26. http://doi.org/10.1525/aeq.2003.34.1.3

Author's information: Michael E. Rolland is a Ph.D. student in Hispanic Linguistics at the Graduate Center, City University of New York (CUNY). He also has an MA in Mediterranean Studies from Middlebury College (Vermont, USA) and a BA in Italian from the University of Wisconsin-Milwaukee. His work focuses on the sociolinguistics of Spanish in multilingual contexts, especially the United States. He currently teaches Spanish language courses at Brooklyn College (CUNY) and is a research assistant at the Center for Integrated Language Communities, a National Language Resource Center funded by the US Department of Education.

Email:mrolland@gradcenter.cuny.edu

To cite this article:

Rolland, M.E. (2016). Ideology, access, and status: Spanish-English bilinguals in the foreign-language classroom. Bellaterra Journal of Teaching \& Learning Language \& Literature, 9(2), 94-114. DOI: http://dx.doi.org/10.5565/rev/jt13.680 